\title{
REVERÊNCIAS À VIDA TERRENA E POST-MORTEM (CAICÓ-RN, SÉCULO XIX)
}

\author{
Marta Maria de Araújo \\ martaujo@digi.com.br
}

Franselma Fernandes de Figueiredo franselmafigueiredo@hotmail.com

Olívia Morais de Medeiros Neta olivianeta@yahoo.com.br

\author{
Universidade Federal do Rio Grande Norte - UFRN
}

\section{RESUMO:}

Ao longo dos séculos XVII, XVIII e XIX, a escrituração de testamentos acrescida, por vezes, de carta de consciência e de autos de contas, era uma prática cultural usualmente exercitada em Portugal e por extensão no Brasil e em Caicó (Rio Grande do Norte), por aqueles segmentos detentores de bens materiais e igualmente simbólicos. Concentrando-se nos testamentos de dois testadores (uma mulher e um homem, solteiros: D. Joaquina Maria do Nascimento e Sr. Gonçalo Correia da Silva), nascidos no município que hoje se denomina Caicó e, igualmente, circunscrição da Freguesia da Gloriosa Senhora Sant'Ana do Seridó, no século XIX, a investigação objetivou interrogar as atitudes devocionais ordinárias e o modus vivendi concernente às (suas) sociabilidades formativas, pela interlocução da história da leitura de Roger Chartier (2001), entendida como portadora de uma sucessão de apropriações variadas, com o território da história social, de conformidade com Ernest Labrousse (1973), que reflete as intersecções entre cultura material e cultura mental. Os indícios, mesmo que mínimos, os traços quase imperceptíveis e os sintomas pontualmente indiciários, notáveis nas linhas e entrelinhas dos testamentos post-mortem, de D. Joaquina Maria do Nascimento e do Sr. Gonçalo Correia da Silva, caucionaram, outrossim, a uma escrita narrativa de suas histórias resumidas de si para outrem.

Palavras-chave: Testamento. Atitudes devocionais. Modus vivendi. Século XIX. Caicó (RN). Freguesia da Gloriosa Senhora Sant'Ana do Seridó.

\section{REVERENCE TO THE EARTHLY LIFE AND POST-MORTEM (CAICÓ CITY-RN, $19^{\mathrm{TH}}$ CENTURY)}

\begin{abstract}
:
Along the $17^{\text {th }}, 18^{\text {th }}$ e $19^{\text {th }}$ centuries, the testimony writings increased, some times, to conscience letter and account papers, was a cultural practice usually carried out in Portugal e, by extension, in Brazil and Caicó City (Rio Grande do Norte), whose were withholder segments of both material and symbolic wealth. Centralized on two testimony's testators (a woman and a man, singles: Lady Joaquina Maria do Nascimento and Mister Gonçalo Correia da Silva), both born on the municipal district that today is called Caicó City and, equally, circumscription of Freguesia of the Gloriosa Senhora Sant'Ana of Seridó, on $19^{\text {th }}$
\end{abstract}


century, the investigation aimed to ask the devoting ordinary postures and the modus vivendi concerned to their formative sociability, by the interlocution of the Roger Chartier's (2001) history of reading, understood as a carrier of a variety succession of appropriations, within the social history's territory, on conformity to Ernest Labrousse (1973), that reflects the intersections between material and mental culture. The indications, even minimal, of traces almost imperceptible and the symptoms punctually indicated, noticeable in the post-mortem testimonies lines and in-between of Lady Joaquina Maria do Nascimento and Mister Gonçalo Correia da Silva, bond to a writing narrative of their resumed histories from themselves to others.

Keywords: Testimony. Devotion attitudes. Modus vivendi. $19^{\text {th }}$ century. Caicó City (RN). Freguesia of the Gloriosa Senhora Sant'Ana of Seridó.

O período de tempo entre 1580 e 1640, consagrado União Ibérica pelas Coroas portuguesa e espanhola, esteve sob os governos dos Monarcas Filipe II (1580-1598), Filipe III (1598-1621) e Filipe IV (1621-1640) da Espanha, ou Filipe I, II e III de Portugal. Por decisão de Filipe II (Filipe I em Portugal), as Ordenações manuelinas, compiladas no reino de Dom Manoel (1495-1521), ou seja, a legislação oficial do reino português teve uma nova compilação com base no Direito Romano, Canônico e Germânico. Esse Código Legislativo, que recebeu a denominação de Ordenações Filipinas, foi aprovado, a 5 de junho de 1595, durante o reinado de Filipe I, mas somente vigorou em 1603 (século XVII), após sua impressão. Consta nas Ordenações Filipinas, por exemplo, as determinações para a escrituração de testamentos, tal como enunciado abaixo:

Querendo alguma pessoa fazer testamento aberto por Tabelião público, podê-lo-á fazer, com tanto que tenha cinco testemunhas varões livres, ou tidos por livres e que sejam maiores de quatorze anos. De maneira que com o Tabelião, que fizer o testamento, sejam seis testemunhas. [...] $\mathrm{E}$ querendo o Testador fazer testamento cerrado, o poderá fazer desta maneira. Depois que escrever, ou mandar escrever seu testamento em que declare sua vontade, o assinará, não sendo escrito por sua mão, por que sendo escrito por sua mão, abastará, ainda que não seja por ele assinado. (ORDENAÇÕES FILIPINAS, 1603, 1870, p. 901).

A escrituração de testamentos, acrescidas por vezes de carta de consciência e de autos de contas, tornou-se uma prática usualmente exercitada nos séculos XVII, XVIII e XIX no Brasil, por extensão em Caicó (Rio Grande do Norte), por aqueles segmentos detentores de bens materiais e outrossim simbólicos. A declaração oral das últimas vontades do(s) testador(es) para com a sua religião, certos deveres sociais e financeiros, e ainda suas "dívidas" com a consciência, era escrita por um testamenteiro, envolto por um cerimonial sóbrio e até austero.

Refletindo sobre a escrituração de testamentos dos séculos XVII ao XIX, no Brasil, Sheila Faria (1998, p. 226) apresenta-os como sendo documentos extremamente ricos em "[...] uma infinidade de detalhes individuais sobre sentimentos e relações familiares [...]", ademais, acrescentamos, concernentes às sociabilidades formativas.

A historiadora esclarece que $\mathrm{o}$ ato de testar seguia geralmente padrões homogêneos redacionais, imperativo formal destinado a "[...] tornar conhecida a vontade do testador a respeito dos procedimentos que deveriam ser tomados para a salvação da 
alma." (FARIA, 1998, p. 226). De todo modo, a essa vontade do testador sobrepunha-se uma atitude de cunho individual e, acima de tudo, uma manifestação da mentalidade coletiva da época, por "força latente" do Código Legislativo português, pelo menos.

Espécie de história de vida resumida de si, especialmente os testamentos de dois testadores (uma mulher e um homem, solteiros: D. Joaquina Maria do Nascimento e Sr. Gonçalo Correia da Silva), nascidos no município que hoje se denomina Caicó e, igualmente, circunscrição da Freguesia da Gloriosa Senhora Sant'Ana do Seridó, no século XIX, constituem o corpus documental de uma investigação que tem por objeto de estudo as histórias de si para outrem. O nosso objetivo é de interrogar as atitudes devocionais ordinárias e o modus vivendi concernente às (suas) sociabilidades formativas, pela interlocução da história da leitura de Roger Chartier (2001), entendida como portadora de uma sucessão de apropriações variadas, com o território da história social, de conformidade com Ernest Labrousse (1973), que reflete as intersecções entre cultura material e cultura mental.

Decerto que nesses testamentos post-mortem, quando interrogados os indícios, mesmo que mínimos, e/ou traços quase imperceptíveis para muitos, e quiçá os sintomas pontualmente indiciários, revelam-se como elementos indeléveis de fenômenos mais gerais: a visão de mundo de uma classe social, a experiência cotidiana... (GINZBURG, 1989). E como bem sublinha Pierre Bourdieu (1997, p. 74), o cursus diverso de uma vida é "[...] inseparavelmente o conjunto de acontecimentos de uma existência individual, concebida como uma história e a narrativa dessa história."

É, pois, por esses indícios, traços e sintomas indiciários (na acepção de Ginzburg) sublinhados nos testamentos post-mortem, de D. Joaquina Maria do Nascimento e do Sr. Gonçalo Correia da Silva, que perscrutamos com pensamento vigilante e atenção cuidadosa - como assim faz o verdadeiro investigador - os elementos reveladores de fenômenos gerais, mas acima de tudo de manifestações pertinentes de práticas culturais apropriadas pelos ensinamentos das leituras religiosas e laicas, da transmissão social oral, das variações da mentalidade luso-brasileira e, outrossim, sertaneja, associadas com a oralidade recitada, com a escrita normatizada e com a escolarização regulada ou não, para um viver religioso e comunitário singulares em vilas e cidades distintas, a exemplo da vila e cidade do Príncipe de então.

Assim, não obstante, para interrogar as atitudes devocionais ordinárias de D. Joaquina Maria do Nascimento, e igualmente, as do Sr. Gonçalo Correia da Silva, construímos, em princípio, a hipótese da existência de maneiras quase comuns de se praticar, aprendida e apreendida mediante uma rede de sociabilidades em que se inclui a leitura silenciosa ou em voz alta, bem como a sua escuta, a partir do texto do livro religioso em igrejas, capelas e oratórios familiares.

É fato que, ao longo do século XIX, os postulados religiosos pregados pela Igreja católica eram divulgados por meio da palavra escrita leitora, que ofertava aos fiéis ensinamentos devocionais construtivos e de contrição, mensagens moralizantes, condutas respeitáveis, costumes imitáveis, decifração de si perante as "leis" de Deus e, fundamentalmente, as "leis" de Deus perante si, de maneira igual, cultuações instrutivas acerca da escolarização.

Esses postulados estavam mais ou menos redigidos sob a forma de ensinamentos transmitidos pela leitura intensiva das obras religiosas em circulação. E tal como nas sociedades européias do antigo regime, os moradores daquela Freguesia e município confrontavam-se com um número reduzido de livros, "[...] que perpetuavam os mesmos textos e as mesmas formas, que forneciam às gerações sucessivas referências idênticas." 
(CHARTIER, 2001, p. 86). Assim, leituras intensivas ou repetidas sobre o texto do livro religioso, lido e relido, ditado ou escutado, recapitulado e associado ao agir cotidiano, reproduziam-se numa rede de práticas culturais de apropriações devocionais misturadas entre pias (espirituais) e profanas (laicas), com seus ensinamentos pedagógicos nos ambientes citadinos e rurais.

No tocante aos livros religiosos, com seus ensinamentos devocionais, há de se perguntar, quais seriam aqueles preferenciais dos leitores ou dos seus ouvintes, em Caicó, no século XIX? Os historiadores Medeiros Filho e Lamartine de Faria (2001) destinaramse a inventariar os religiosos e laicos que lá circularam nos territórios e nas fazendas da Freguesia da Gloriosa Senhora Sant'Ana do Seridó, por volta desse século XIX. Por esse inventário circulou Imitação de Cristo (1419 e 2005), dentre os livros religiosos, como objeto cultural, que se agasalhavam em bancas de oratórios, baús e possivelmente em gavetas de acomodar papéis, e outros guardados de estimação.

Para se pensar a leitura textual sob o livro religioso, dirigida para ensinamentos pedagógicos de atitudes devocionais, dentre muitos outros, requer necessariamente que o ato da leitura vista como intensiva seja refletido como situado "[...] numa rede de práticas culturais apoiadas sobre o livro [que engloba ou que absorve]: a escuta de textos lidos e relidos em voz alta, na família ou na Igreja, a memorização desses textos ouvidos, mais reconhecidos do que lidos, sua recitação para si e para os outros." (CHARTIER, 2001, p. 86). Para esse historiador francês, a leitura intensiva proporcionava, inevitavelmente, a intimidade com o livro lido ou ditado, cujo texto tornava-se referência familiar para as maneiras de pensar, de agir rotineiramente e de conviver social e religiosamente.

A escrita de uma história cultural da leitura, em grande parte sublinhada pelo trajeto da palavra leitora escrita dos livros de leitura religiosos e laicos, recitados e ditados em voz alta, recapitulados e associados ao agir cotidiano, induz-nos a pensar, como faz ver Ginzburg (1989, p. 168), que o "[...] acesso a determinadas experiências [era] cada vez mais mediado pelas páginas dos livros."

Daí, a indispensável investigação do entrelaçamento do livro religioso lido, ditado ou escutado, na então Vila do Príncipe e Cidade do Príncipe, com os seus ensinamentos de atitudes devocionais pias e profanas para a existência de si, assim podermos estabelecer um contraponto com suas apropriações e absorções culturais, materiais e mentais, incluindo os ensinamentos escolares, a partir de indícios, traços e sintomas sublinhados nos testamentos dos dois testadores ora analisados.

O livro de leitura para formação religiosa - Imitação de Cristo - é, indiscutivelmente, de gênero devocional. Ciente desse gênero, indagamos: quais os específicos ensinamentos devocionais apregoados por esse objeto cultural? E numa indagação mais ampla, quais seriam os laços desses ensinamentos com a oralidade, a leitura, a escrita e ainda a escolarização?

O livro de original latino manuscrito, data do ano de 1419, tendo sido escrito pelo monge agostiniano Tomás de Kempis (1380-1471), que viveu no Mosteiro de Sant'Ana, localizado em Zwolle, distrito de Utrecht, Alemanha. Espécie de um guia espiritual auxiliar e unificador de práticas cristãs católicas devocionais, bem ainda um tratado de moral cristã, essa obra representa um dos mais antigos textos religiosos de leitura intensiva sendo, inclusive, considerada uma segunda Bíblia, igualmente traduzida para inumeráveis línguas vernáculas e o latim. (MEDEIROS FILHO; LAMARTINE DE FARIA, 2001; HALE, 1983).

A propósito desse tratado de moral cristã, cabe destacar a percepção do historiador da educação, o italiano Franco Cambi (1999, p. 181, grifo do autor): “[...] os 
textos de formação espiritual (tipo Imitação de Cristo) agem com fim educativo plasmando a visão da religião, interpretando os valores do cristianismo, propondo modelos de formação cristã." Um exemplo a tal respeito, remete para os Irmãos de Vida Comum, assim como Santo Ignácio de Loyola, Santa Teresa de Ávila, dentre muitos outros. (DICKENS, 1972).

Nos oitocentos, tornou-se comum os religiosos e os leigos lerem comentando, ditando e recapitulando, em vista da sua palavra leitora ensinar um conjunto de atitudes devocionais quase encadeadas, principiando por um contínuo de ensinamentos inclinados para uma vida espiritual de boa-fé, compartilhada de si para si mesmo, e de si para outrem, donde tais atitudes deverão "[...] ser o nosso maior empenho: vencermo-nos a nós mesmos, tornamo-nos a cada dia mais fortes e fazer algum progresso no bem. [...] O homem bom e piedoso dispõe no seu interior as obras que há de fazer externamente." (KEMPIS, 2005, p. 16).

Da intensidade da palavra leitora lida, relida ou escutada sobre os textos desse livro, provinham, inegavelmente, os ensinamentos de uma maneira de praticar as atitudes devocionais pias e profanas, para a comunidade de fiéis seguidores do credo católico: ler continuamente, buscar a paz e a perfeição dos santos pela simplicidade de ser e de agir, mortificar-se "[...] inteiramente em todos os desejos terrenos e assim puderem, no íntimo de seu coração, unir-se a Deus e atender livremente a si mesmos." (KEMPIS, 2005, p. 22).

A palavra leitora de Imitação de Cristo traduzia-se, doravante, num ato de contrição entre a vida terrena e a vida espiritual antes e pós-morte. Por princípio de vida existencial, havia que se aprender pela palavra lida e apregoada, pois,

Enquanto viveres, estarás sujeito ao variável, ainda que não queiras; ora te acharás alegre, ora triste, ora sossegado, ora perturbado, umas vezes fervoroso, outras tíbio, já diligente, já preguiçoso, agora sério, já leviano. [...] O sábio, porém, é instruído na vida espiritual, está acima dessa inconstância, não cuidando dos seus sentimentos, nem de que parte sopra o vento da instabilidade, mas concentrando todo o esforço de sua alma no devido e almejado fim. [...] Porque assim poderá permanecer sempre o mesmo e inabalável, dirigindo a mim, sem cessar, a mira da sua intenção, entre todas as vicissitudes que lhe sobrevierem. [...] Quanto mais pura for a sua intenção, tanto maior será a tua firmeza durante as diversas tempestades. (KEMPIS, 2005, p. 104).

A palavra leitora do texto Imitação de Cristo é, em si, extremamente didática. Ela evoca e (re)evoca ritos da iniciação cristã: define, conduz o leitor, a leitora, enfim, o ouvinte cristão para exercitar inúmeros atos devocionais no decorrer do dia-a-dia; dever orar pela manhã, tarde e noite; repetir sempre o Ofício Divino (comumente chamado de Oração das Horas pelos salmos); recolher-se para exame de consciência; prestar devoção fervorosa aos santos e santas da Igreja Católica; assistir piedosamente missas; ir ao encontro do sacramento da comunhão, “[...] pois não há oferenda mais meritória, nem maior satisfação para apagar os pecados, do que oferecer-se pura e inteiramente a Deus, na missa e na comunhão, juntamente com a oblação do corpo de Cristo." (KEMPIS, 2005, p. 154).

Ora, uma história da leitura, entendida como história de uma prática cultural que se encontra situada numa rede de apropriações de outras práticas culturais, requer que se considerem as atitudes devocionais apreendidas e moldadas à vida diária, como sugere Chartier (1990, p. 136), nas intrincações de seus ensinamentos pedagógicos, para assim 
“[...] reconstituir trajetórias complexas, da palavra proferida ao texto escrito, da escrita lida aos gestos feitos, do livro impresso à palavra leitora [...]."

As apropriações ou mesmo as absorções culturais da palavra leitora dos textos de Imitação de Cristo, direcionada para ensinamentos de maneiras de praticar atos e atitudes devocionais, conduz-nos a reconstituir aquele procedimento que nos orienta Chartier - da leitura da escrita lida, ditada ou escutada à escrituração da palavra ditada nos testamentos dos nossos dois testadores - para assim reescrever suas histórias resumidas de si para outrem, que se encadeiam e enfeixam apropriações de atitudes devocionais num primeiro plano, para fins deste trabalho.

Procurando, num segundo plano, interrogar o modus vivendi e as sociabilidades formativas a partir dos testamentos daqueles dois testadores habitantes da Vila do Príncipe e da Cidade do Príncipe da Freguesia da Gloriosa Senhora Sant'Ana do Seridó, no século XIX, partimos do entendimento de Ernest Labrousse (1973), de que à história social cabe refletir acerca das intersecções entre cultura material e cultura mental, ou entre o econômico, o social e as idéias epocais.

Desde a Povoação do Caicó (1735), que foi elevada à Vila do Príncipe (1788), à Cidade do Príncipe (Lei Provincial no 612, de 15 de dezembro de 1868) e, finalmente, à Caicó (Decreto $\mathrm{n}^{\circ} 33$ de 7 de julho de1890), o modus vivendi dos seus moradores se distribuía distintamente pela vida familiar com a religiosa, a econômica com a social e a política, enfim, em instâncias culturais afeitas às convivências hierarquizadas.

Em grande parte, a instalação da Povoação do Caicó esteve associada às instituições jurídicas, como a Casa da Suplicação; à instituição católica, representada pela Capela, sob a invocação da Senhora Sant'Ana (ATA DE INSTALAÇÃO DA POVOAÇÃO DO CAICÓ, 1735, 1984) e, posteriormente, à criação da Freguesia da Gloriosa da Senhora Sant'Ana do Seridó, datada de 1748.

Nesse século XVIII, a 31 de julho de 1788, quando a Povoação do Caicó foi elevada à Vila do Príncipe, institucionalizou-se assim o município representado pelo Senado da Câmara, cujo primeiro presidente foi Antônio da Silva e Souza. Indicam os trabalhos de Medeiros Filho (2002) e de Câmara Cascudo (1955), a presença oficial do Desembargador Antônio Felipe Soares de Andrade Brederode, da Comarca da Paraíba. Para tanto, "O Tenente-Coronel Antônio Garcia de Sá Barroso, em carta de 15 de agosto desse 1788, para o Senado da Câmara de Natal, informava que o Sr. Desembargador teve formado por Vila nesta ribeira a 31 de julho passado." (CASCUDO, 1955, p. 113).

Com a Independência política do Brasil, a Constituição Imperial de 1824 autorizou a criação de câmaras municipais, regulamentadas pela Lei de $1^{\circ}$ de outubro de 1828, tratada como a Lei Orgânica dos Municípios. Às câmaras das cidades compostas de nove membros, e das vilas de sete, competiam o governo econômico e municipal. (CONSTITUIÇÕES BRASILEIRAS, 1824; LEI DE $1^{\circ}$ DE OUTUBRO DE 1828, 2001). Cabialhes deliberar sobre a tranqüilidade, a segurança, a saúde e a comodidade dos habitantes da urbe e arredores, por posturas municipais e regulamentos dos edifícios públicos.

Por decorrência dessa Lei de 1828, a Câmara Municipal da então Vila do Príncipe aprovou, em 1835, as primeiras posturas da municipalidade. Passados trinta anos da regulamentação dessa Lei de 1828, a Assembléia Provincial autorizou a instalação do foro da Comarca do Seridó (Resolução Provincial no 365, de 19 de julho de 1858), englobando os termos judiciários da Vila do Príncipe e do Acari. Antes, fez parte como termo judiciário, da comarca da Paraíba (1788- 1818), da comarca de Natal (1818-1835) e da comarca do Assu (1835-1788). (LIMA, 1990; LYRA, 1998). 
É nesse contínuo para prover a estrutura e a alteridade religiosa, social, econômica, política e jurídica da Povoação do Caicó, da Vila do Príncipe, da Cidade do Príncipe, de Caicó, circunscrições da Freguesia da Gloriosa Senhora Sant'Ana do Seridó, que interrogamos o modus vivendi e as sociabilidades formativas tidas e havidas, pelo crivo dos testamentos (incluindo os autos de contas) dos dois testadores moradores da Vila do Príncipe e da Cidade do Príncipe, pressupondo aquele entendimento de Ernest Labrousse (1973), de que à história cabe refletir acerca das intersecções entre cultura material e cultura mental.

Pode-se, observar, nesses testamentos escriturados por tabeliães, escrivães ou mesmo por familiares, algumas das instâncias de sociabilidades reinantes em Caicó, no século XIX, a exemplo das casas de morada, igrejas, capelas, oratórios, irmandades, repartições públicas (Administração da Renda, Coletoria e Tesouraria Provincial). No plano das idéias e da existência material, percebemos que o século XVIII emprestou para grande parte do XIX, um modus vivendi católico prolongado, quase inalterado. Sob a égide da liturgia católica, apostólica e romana,

Católico que honrasse o nome não se limitava a cumprir a obrigação pascal e os mandamentos da Santa Madre Igreja: convinha alimentar sua vida espiritual privada e comunitária. [...] participar das cerimônias e devoções públicas, umas dentro, outras fora dos templos, tais como celebrações da Semana Santa, as freqüentes procissões, bênçãos do Santíssimo, trezenas, novenas e tríduos dedicados aos múltiplos oragos de sua freguesia [...]. (MOTT, 1997, p. 159-160).

Um sintoma da propagação dessa postulação encontra-se no modus vivendi no que se refere às práticas de sociabilidades formativas, da então Vila do Príncipe da Freguesia da Gloriosa Senhora Sant'Ana. O historiador Macedo (2005, p. 66) descreve a propósito: "Sua vida religiosa [do sertanejo de Caicó] resumida às devoções domésticas, ao terço rezado ao cair da noite, às novenas recitadas nas datas santas necessitava de uma melhor acomodação sob o teto de templos católicos e sob a autoridade dos padres."

Evidentemente que a história de toda uma vida dos nossos dois testadores, nascidos na Freguesia da Gloriosa Senhora Sant'Ana, está intimamente ligada com a cultura material de uma dada coletividade representada pela freguesia, a municipalidade, o modus vivendi urbano e rural e, igualmente, as sociabilidades formativas ali enraizadas e cultivadas. As histórias de vida de si são assaz sujeitas das idéias mentais aprendidas pelos ensinamentos da palavra leitora dos textos dos livros de leitura religiosos e laicos, da palavra ditada, da palavra memorizada, da transmissão de práticas sociais e de atitudes devocionais professadas e repassadas.

No século XIX, mulheres e homens acumularam parte considerável de seus conhecimentos práticos e teóricos e, outrossim, hábitos de vida comunitários, por suas inserções numa rede de relações sociais muito mais intrincada do que diversificada, que cada vez mais rareava apartar a oralidade da leitura, da escrita e da escolarização. Esse desapartamento já pregava o monge agostiniano Tomás de Kempis que viveu nos séculos XIV e XV. Pelos seus ensinamentos dirigidos para uma maneira de exercitar,

Não é reprovável a ciência ou qualquer outro conhecimento das coisas, pois é boa em si e ordenada por Deus; sempre, porém, devemos preferir a boa consciência e a vida virtuosa. [...] Muitos, porém, estudam mais para saber, que para bem viver, por isso erram amiúde e pouco ou nenhum fruto colhem. [...] Oxalá a sua vida tenha correspondido à sua ciência; 
porque, destarte, terão lido e estudado com proveito. (KEMPIS, 2005, p. 16-17).

Foi graças à oralidade, à leitura, à escrita, à escolarização elementar e às mentalidades coletivas costumeiramente preservadas, que D. Joaquina Maria do Nascimento por se encontrar enferma, ditou a escrituração do seu testamento, cujo testamenteiro foi seu próprio sobrinho, João Rodrigues Mariz.

D. Joaquina Maria do Nascimento, cidadã brasileira, natural da Freguesia da Gloriosa Senhora Sant'Ana do Seridó, nascida em 1791, filha legítima do Tenente Coronel Manoel Pereira Monteiro e D. Theresa Maria da Conceição (falecidos), moradora do Sítio Curral Queimado, pertencente à Vila do Príncipe, solteira e sem filhos, exercitava relativamente a liturgia católica, apostólica e romana, devidamente em virtude das apropriações e das absorções culturais da palavra leitora ensinada e ditada dos textos de Imitação de Cristo, por exemplo.

O ano de 1850 (data da escrituração do testamento) era ainda um tempo, no Brasil e no Rio Grande do Norte, que mulheres de bens materiais e simbólicos, como a D. Joaquina, insistiam em não dominarem a escrita já prestigiada, podendo bem ler. Nos termos do que recorda Labrousse (1973, p. 22), a respeito das travas de uma específica estrutura social, "A mentalidade de um meio muda mais lentamente do que o próprio meio."

Contudo, para um povo profundamente católico, como o seridoense, não se poderia ignorar, em nome de uma comunidade de fiéis pertencentes à Freguesia da Gloriosa Senhora Sant'Ana, a exercitação de atos devocionais pios ou mesmo profanos, comumente professados. Ora, ser católico praticante representava, pelos ensinamentos da palavra leitora do credo católico, repetir ou recapitular por várias vezes ao dia a leitura ou a escuta do Ofício Divino, alternada por cânticos e penitências.

Numa espécie de aliança de fidelidade e de respeito pelos atos devocionais misteres da Igreja Católica, D. Joaquina, lúcida e moribunda, vivificou aqueles de seus feitos gerais para escriturá-los no seu testamento. Com moderação e contrição, ditou:

Primeiramente encomendo minha Alma ao Todo Poderoso que [me criou], e lhe Rogo pelos merecimentos do Preciso Sangue de meu Senhor Jesus Cristo que me salve. Rogo [...] a Gloriosa Senhora Sant'Ana minha Padroeira, ao Anjo da minha Guarda a Santa do meu nome, e a todos os Santos e Santas da Corte do Céu queiram interceder por mim ao Senhor, para que a minha Alma entre segura na Glória para que foi criada. (NASCIMENTO, 1850, fl. 1).

Se mulheres e homens católicos haveriam de externalizar no plano material, atitudes devocionais profanas como ensinava Imitação de Cristo, que esparsos indícios e/ou traços podem ser perceptíveis nos testamento post-mortem, minimante reveladores do exercício da apropriação mental desses ensinamentos a partir do modus vivendi singular de D. Joaquina?

Certamente que a benignidade com ela mesma, e com o Todo Poderoso Deus tornou-a uma celibatária sem filhos. Dos deveres imperiosos das obras de misericórdia com a Igreja Católica, com a justiça temporal e com os seus parentes de sangue, D. Joaquina redistribuiu seus bens acumulados com estima, mais a uns, do que a outros. Aos sobrinhos afilhados, Manoel Pereira Mariz Junior e Theresa Maria, um valor de dez mil réis. O restante dos seus bens financeiros e materiais (envolvendo os escravos Maria, 
Vicência e Luiz) repartiu, com dever de eqüidade, para os seus universais e legítimos herdeiros - os dez filhos da sobrinha e afilhada Rosa Maria do Espírito Santo, casada com o seu sobrinho João Rodrigues Mariz, seu testamenteiro e assinante por sua expressa cláusula: “[...] por eu não saber escrever roguei a meu sobrinho João Rodrigues Mariz, este por mim assinasse depois de me ter dito lido - Dia Era ut Retro [...]. Está tudo igual ao que é ditado e por isso o mandei assinar pelo dito meu sobrinho." (NASCIMENTO, 1850, fl. 2, grifo nosso).

O tempo da vida terrena, de dedicação ao trabalho, de penitências e de atos devocionais pios e profanos, era igualmente o tempo de encomendar a salvação da alma. A especificidade dos atos devocionais pios apropriados por D. Joaquina, segundo a palavra leitora ensinada e ditada nos textos de Imitação de Cristo combina-se, doravante, com as práticas de sociabilidades formativas, principalmente as religiosas. Da devoção à Gloriosa Senhora Sant'Ana assistia às missas e novenas da santa padroeira, no mês de julho, na matriz da Vila do Príncipe. Da profunda submissão aos mandamentos das leis de Deus e das parábolas e exemplos de Jesus Cristo, decorria a sua participação em cerimônias de batizados e de casamentos de irmãos, sobrinhos e parentes próximos em igrejas, capelas e em oratórios domésticos. Os deveres com os tributos rurais e as sisas (impostos) dos escravos adquiridos, dentre outros bens, conduziam as repartições públicas, como a Procuradoria Fiscal e a Coletoria Provincial da Vila do Príncipe, pelo menos.

É evidente que um modus vivendi mais amplo condicionava e estimulava as práticas de sociabilidades formativas, que englobavam preferencialmente a esfera familiar quase autônoma no tratamento da saúde, na escolarização das crianças por mães ou mestreescola, na produção caseira de toda dieta alimentar, na confecção dos utensílios domésticos, do trabalho pecuarístico e a habitação (conjunta) de outros familiares e serviçais.

Do ponto de vista estrito do modus vivendi na Freguesia da Gloriosa Senhora Sant'Ana, intercedido pela cultura material e a cultura mental, há que indagar o que transparece no testamento e nos autos de contas de D. Joaquina? A história de uma vida de católica praticante, devota da Gloriosa Senhora Sant'Ana e da santa Joaquina, de relativa cumpridora de atos devocionais pios e profanos, de um agir cotidiano segundo a interpretação dos mandamentos, culminando com a sua determinação em ditar o rito da cerimônia fúnebre do seu sepultamento, cuidadosamente cumprido em 10 de agosto de 1851, dia de sua morte, causada por uma pneumonia.

Aos sessenta anos de idade, D. Joaquina, por ser solteira, foi sepultada envolta de um hábito branco e devidamente assistida por todos os sacramentos, como assim ordenavam os mandamentos da madre Igreja Católica. Na escrituração do seu testamento, prenunciou, por palavras ditadas em voz alta, o seu velório e enterro de mulher cristã e proprietária de bens materiais e simbólicos. À semelhança das santas e santos. ordenou:

Meu corpo envolto em hábito branco será sepultado na Capela de Nossa Senhora do Ó de Serra Negra, onde estão sepultados os meus predecessores, acompanhada pelo Sacerdote que ali estiver de Capelão havendo, em não havendo será de forma que puder ser, de grade acima, e havendo Capelão este dirá por minha Alma Missa de Corpo presente. (NASCIMENTO, 1850, fl. 1).

Todos esses costumes ensinados, preservados, absorvidos e professados equivalentes a um modus vivendi de mulheres e homens católicos da Vila do Príncipe e por extensão da Freguesia da Gloriosa Senhora Sant'Ana, foram rigorosamente cumpridos 
pelos familiares e pelo reverendo Joaquim Felix de Medeiros. Como bem destaca Le Goff (2002, p. 244): "O encontro dos vivos e dos mortos no seio das grandes famílias se dá nos cemitérios." Por outras palavras, os momentos de sepultamentos sobressaem como ocasiões oportunas de sociabilidades fúnebres.

Com a altivez de mulher católica de família tradicional do sertão do Seridó, proprietária de terra, de gado, de escravos, de jóias, esse encontro seria material e simbolicamente ornado por missa, velas, encomenda e cortejo do corpo até a cova acima das grades da capela de Nossa Senhora do Ó da então Povoação de Serra Negra. De onde vinha essa apropriação ou absorção cultural de D. Joaquina?

Ainda século XVIII, o Tenente Coronel Manoel Pereira Monteiro (seu pai), ergueu em sua fazenda Serra Negra, uma capela em homenagem à Nossa Senhora do Ó. Quando do seu falecimento, em 1820, com mais de noventa anos de idade, "[...] seu corpo foi amortalhado em hábito de Carmelita, acompanhado por mim e sepultado na Capela de Nossa Senhora do Ó da mesma Fazenda, no dia seguinte, como havia pedido no Testamento." (LIVROS DE ÓBITOS, 1811-1838, [1961], fl. 51). Trata-se, sem dúvida, de uma apropriação cultural de maneiras de praticar por familiares próximos que ganhavam perenidade.

Pela via do recibo do funeral e do enterro da finada D. Joaquina Maria do Nascimento, vê-se a interdição da cultura material e da cultura mental no modus vivendi, com suas sociabilidades formativas referenciadas por códigos de conduta, atitudes devocionais pias e profanas.

$\begin{array}{lc}\text { Ofício paroquial } & 10 \$ 000 \\ \text { Caminho ao Pc. do pároco } & 7 \$ 000 \\ \text { Do pagamento de padre Joaquim Felix de Medeiros } & 4 \$ 000 \\ \text { Velas do corpo } & 1 \$ 600 \\ \text { Acompanhamento, encomendação e vela } & 1 \$ 280 \\ \text { Missa de corpo presente } & 1 \$ 000 \\ \text { Sacristão } & \$ 520 \\ \text { Cova a acima das grades } & 4 \$ 000 \\ \text { Visita da cova } & - \\ \text { Caminho ao padre Joaquim Felix de Medeiros } & 4 \$ 000 \\ \text { Memento } & 2 \$ 000 \\ \text { Missa de } 7^{\circ} \text { dia } & 1 \$ 000 \\ \text { Velas da sepultura } & 1 \$ 600 \\ \text { Soma } & 38 \$ 000\end{array}$

A escrituração das últimas vontades do testador para com suas atitudes devocionais pias e profanas, intrínsecas à religião católica e a certos deveres sociais e financeiros, mais do que um ato de documentar, traduzia-se ademais num desejo simbólico de recordação de si por outrem ante o designo da morte. A história de vida resumida de D. Joaquina Maria do Nascimento, indicia, então, a pensar a história de vida (resumida) do Sr. Gonçalo Correia da Silva.

No apogeu dos movimentos de contestação da escravidão no Brasil, da aprovação da Lei Eusébio de Queiroz (1850), que pôs fim ao tráfico negreiro, e da sanção da Lei do Ventre Livre (1871), dando liberdade aos filhos de escravos nascidos a partir de então, 
viveu o Sr. Gonçalo Correia da Silva, no sítio Riacho de Fora, de sua propriedade, natural e morador do município da Cidade do Príncipe, pertencente à Freguesia da Gloriosa Senhora Sant' Ana.

O Sr. Gonçalo Correia da Silva, um cidadão brasileiro, filho de Manoel da Rocha Freire e Maria Teresa de Jesus (falecidos), assim como D. Joaquina, mantiveram-se solteiros e sem filhos. Alfabetizado na oralidade, na leitura, na escrita e na doutrina católica, ditou o seu testamento para o tabelião público, Inácio Gonçalves Vale, já em estado avançado de uma ferida cancrosa (possivelmente um cancro venéreo). Pesquisadores da história local, como Dom Adelino Dantas (1979) reportam-se para as causas mortis dos seridoenses nos séculos XVIII e XIX (especialmente entre 1789 a 1834), em que se sobressaem o cancro e um número sem conta de feridas de toda espécie, conforme os livros de óbitos da Freguesia da Gloriosa Senhora Sant'Ana e das suas capelas (Acari, Currais Novos, Jardim do Seridó, Jardim de Piranhas e Serra Negra).

Decididamente, por palavras proferidas e por gestos investidos numa maneira de agir, externalizou os seus últimos atos devocionais, os rogos de merecimentos e a encomenda da sua alma para Deus. A princípio, anunciou seu estado físico, mental e devotamentos.

Eu Gonçalo Correia da Silva achando-me bastante doente de uma ferida cancrosa, porém em meu perfeito juízo e entendimento que Deus foi servido dorme e não sabendo o dia em que o mesmo Deus será servido a chamar-me, faço este meu testamento pela forma e maneira seguinte, hoje neste Sitio Riacho de Fora, onde moro aos três dias do mês de Agosto de mil oito centos e setenta e três. Primeiramente encomendo a minha Alma a Deus que criou e lhe rogo pelos merecimentos do preciso sangue de Jesus Cristo a Salve. [...] Rogo a Maria Santíssima, mãe e advogada dos pecadores, ao Anjo da Minha Guarda, ao Santo do meu nome e a todos os santos da Corte do Céu que irão ser meus intercessores no perigo transposto desta vida para a outra vida para que a minha Alma entre segura na Glória. (SILVA, 1873, fl. 1).

O que reter das palavras ditadas e escrituradas no corpo do testamento do Sr. Gonçalo sobre os seus específicos modus vivendi e suas sociabilidades formativas? $\mathrm{O}$ modus vivendi desse homem católico, bem próprio do ambiente do sertão nortista rural e da ribeira seridoense, basicamente circunscrevia-se, tanto por herança familiar quanto por especialização econômica da época, ao criatório do gado vacum, destinado à dieta alimentar de carne e leite e a troca monetária, bem como ao aproveitamento do couro para venda e para a confecção de objetos úteis da casa da fazenda e demais cômodos.

$\mathrm{O}$ modus vivendi do meio rural nortista e seridoense demandava fábricas (oficinas) destinadas à confecção dos objetos usuais, para a empresa rural de atividades pastoris e criatórios. No sitio Riacho de Fora, que reproduzia uma rotina de trabalho exaustiva e certamente rude, servia-se o Sr. Gonçalo da força do trabalho escravo e da mão-de-obra livre. Possuía uma escrava de nome Severiana, um escravo de nome Eliseu, e aparentemente a mão-de-obra de um trabalhador livre de nome Targino Batista da Silva, pelo menos. Todavia, como assinala Macêdo (2005), os donos de fazendas conheciam muito bem dos fazeres em que ordenava para seus subordinados.

E as sociabilidades formativas do Sr. Gonçalo Correia da Silva? É havido e sabido que no século XIX, os ritos religiosos e as atitudes devocionais singelos da Igreja Católica, ensinados, recapitulados, apropriados e absorvidos, ramificavam-se pelas fendas das demais sociabilidades formativas. Tendo por referência a vida colonial no Brasil e por 
extensão a de Caicó, no século XVIII, que pode ser estendida para grande parte do século XIX, como ressalva Macedo:
A vida espiritual católica confundia-se com a vida civil, os ritos religiosos amalgamando-se com os expedientes civis. [...] Constituída como autoridade pública na colônia, a Igreja regulamentava as práticas espirituais dos indivíduos, exercia a assistência social e o ensino e normatizava as diversões públicas. (MACÊDO, 2005, p. 71).

Nessa fronteira demasiadamente tênue entre o território do religioso e o território do profano ou laico, o Sr. Gonçalo reproduziu o modus vivendi predominante e cumpriu grande parte de suas sociabilidades formativas. Atos litúrgicos católicos (missas, novenas, festejos da padroeira), bem como as celebrações de casamento das irmãs e dos irmãos, os batizados e a primeira comunhão dos sobrinhos, as festas nas fazendas da parentela, quase todos intermediados pela Igreja Católica, igualmente os leilões de gado e de escravos nas feiras livres da Vila do Príncipe e depois da Cidade do Príncipe, comporiam em grande parte o rosário das sociabilidades formativas do sertanejo Gonçalo Correia da Silva.

Se a história da leitura é aqui entendida como uma história de práticas culturais que se situa numa rede de apropriações de outras práticas culturais, leva-nos a reconstituir a trajetória da palavra proferida no texto escrito, pelo gesto cultural da palavra ditada para seu testamento. Seria possível, a partir de um e outro, dizer que, dentre as suas últimas vontades em vida, o Sr Gonçalo discriminou o cumprimento da missa de corpo presente por sua alma, mais duzentos e cinqüenta capelas de missas também por sua alma, mais cinqüenta celebradas pela alma dos seus pais, além de seis ditas pelas almas do purgatório.

A vaidade inigualável das elites locais, com suas práticas católicas cimentadas, situava-se numa rede circulante para apropriações diversas sobre o livro, a leitura, a oralidade e a escolarização. Assim sendo, o prestígio de certas sociabilidades formativas levou o Sr. Gonçalo a destinar ao padre Manuel Salviano de Medeiros a quantia monetária de trinta e hum mil e duzentos e quarenta réis, para a devida assistência espiritual no decorrer de todo o seu funeral, cobrindo a celebração da missa de corpo presente e o acompanhamento do cortejo fúnebre até o cemitério, com a decência necessária a todo morto que se transportava da vida terrena para a outra, para que a sua alma entrasse segura na glória de Deus. (SILVA, 1873).

No limiar da morte, amargando dor física e moral de um possível cancro venéreo, o $\mathrm{Sr}$ Gonçalo procurou ainda mais compensar as vicissitudes humanas que lhes sobrevieram, pelo gesto da associação entre a palavra lida ou escutada e a palavra praticada. Por palavras aparentemente reveladoras de atitudes devocionais profanas, repartiu seus legítimos bens materiais, herdados em parte dos pais, por cinco espécies de destinatários socialmente distintos. Em primeiro lugar, a irmã Maria - a quem deixou a casa do sítio Riacho de Fora, como gesto de gratidão pela atitude caridosa com que tratava da ferida cancrosa de que fora acometido. Em segundo lugar, os sobrinhos afilhados, Manoel, João, Ignácio e Maria - aos quais destinou todo o gado vacum fêmea. Em terceiro lugar, o afilhado filho do caboclo Targino - a quem concedeu uma podra de segunda muda. Em quarto lugar, a escrava Severiana - a quem destinou duas novilhas. Em quinto lugar, todos os irmãos e irmãs - aos quais assegurou o restante de todos os seus bens materiais e financeiros.

Ademais, para a mercê de uma morte com o consolo da pena reduzida dos pecados capitais e veniais cometidos, o Sr. Gonçalo declarava forro o seu escravo Eliseu, a quem, após a sua morte, o seu testamenteiro passaria a sua carta de liberdade. Com esse 
gesto político e cristão, o Sr. Gonçalo, ou cumpria a Lei do Ventre Livre (1871), ou exercitava uma atitude devocional profana, ensinada e apropriada por meio da palavra leitora lida ou ditada de textos religiosos do gênero Imitação de Cristo. Um dos ensinamentos desse gênero devocional remete para a existência individual e social de homens e mulheres católicos, que, revestidos pelas leis de Deus e pelo progresso de atitudes devocionais profanas ou pias, exercitassem "[...] ler ou escrever ou rezar ou meditar ou fazer alguma coisa de proveito comum. [...] Renuncia à curiosidade e escolhes leituras tais, que mais sirvam para cumpungir que para distrair." (KEMPIS, 2005, p. 31-32).

Concentrando seus últimos desejos pios para a devida e almejada salvação da sua alma, o cidadão alfabetizado Gonçalo rogava, como última vontade em perfeito juízo e entendimento da grandeza de Deus, a honestidade dos seus testamenteiros na partilha de seus bens por herdeiros legítimos e instituídos. E, centrando na formalidade da escrituração de seu testamento, ressalvou:

Tendo por concluído todas as disposições de última vontade, e pedi ao Senhor Tabelião Inácio Gonçalves Vale que não podendo eu escrever este meu testamento o escrevesse, o qual foi por mim ditado, e sendo lido assim e achando em tudo conforme o que havia ditado e assinei de meu próprio punho $=$ Gonçalo Correia da Silva. (SILVA, 1873, fl. 2, grifo).

As histórias de vida (resumida) de si para outrem de D. Joaquina Maria do Nascimento e do Sr. Gonçalo Correia da Silva, reescritas a partir dos seus testamentos, revelam-se como histórias de si recortadas por práticas sociais religiosas de um modus vivendi do século XIX, na Vila do Príncipe e na Cidade do Príncipe, circunscrições da Freguesia da Gloriosa Senhora Sant'Ana do Seridó.

Os específicos modus vivendi de D. Joaquina e do Sr. Gonçalo, no que concerne às suas atitudes devocionais e às suas sociabilidades formativas, puseram-se em concórdia com a mentalidade coletiva da época, por "força latente" de códigos impostos, da leitura silenciosa ou em voz alta sobre o texto do livro religioso ou laico, da escuta da leitura dita ou ditada, e, ademais, da escolarização. Apreender essas interseções sublinhadas pelas histórias de vida [resumidas] de D. Joaquina e do Sr. Gonçalo é perceber o quão era próxima a educação (no sentido amplo) da mulher e do homem seridoense, entretecida doravante por uma rede de apropriações ou absorções de práticas sociais e espirituais e ritos planificados no seio da vida terrena. Sólida e perena, essa ativa estrutura mental de práticas, absorvidas por ritos, símbolos e solidariedades, estimulava a crença na eficácia das penas purgatórias por meio de sufrágios de missas, de orações e de obras pias caridosas e misericordiosas em intersecção dos santos padroeiros, parentes e serviçais.

Na tradição dos instrumentos sutis de controle social, os testamentos post-mortem atualizavam às autoridades políticas e religiosas portuguesas, e posteriormente brasileiras, indícios, traços e sintomas elucidativos do quantum dos bens materiais dos testadores e de seus destinatários pela redistribuição acordada, das possíveis dívidas públicas e privadas, dos atos devocionais professados peculiares de um modus vivendi ateniente às sociabilidades formativas, e também das leituras e das escutas de ensinamentos ligados àqueles atos devocionais.

Reiteradamente (re)afirmados e revistos, os indícios, mesmo que mínimos, os traços quase imperceptíveis e os sintomas pontualmente indiciários, notáveis nas linhas e entrelinhas dos testamentos post-mortem, de D. Joaquina Maria do Nascimento e do Sr. Gonçalo Correia da Silva, caucionaram uma escrita narrativa de suas histórias resumidas de si para outrem. 


\section{Referências}

BOURDIEU, Pierre. Razões práticas. Sobre a teoria da ação. Tradução Mariza Corrêa. $1^{\text {a }}$ reimp. Campinas: Papirus, 1997.

BRASIL. Constituições brasileiras - 1824. Brasília: Senado Federal, 2001. (v. 1, organizado por Octaciano Nogueira).

Lei de $\mathbf{1}^{\circ}$ de outubro de 1828. Dá nova forma às Câmaras Municipais, marca suas atribuições, e o processo para sua eleição, e dos Juízes de Paz. Disponível em: <www.brasilimperial.org.br/const1824.htm> Acesso em: 16 jul. 2008.

CAMBI, Franco. História da pedagogia. Tradução Álvaro Lorencini. São Paulo: Editora UNESP, 1999.

CASCUDO, Luís da Câmara. História do Rio Grande do Norte. Rio de Janeiro: Ministério da Educação e Cultura/Serviço de Documentação/Departamento de Imprensa Nacional, 1955.

CHARTIER, Roger. A história cultural: entre práticas e representações. Tradução Maria Manuela Galhardo. Rio de Janeiro: Bertrand Brasil; Lisboa: Difel, 1990.

Do livro à leitura. In: CHARTIER, Roger. (Org.). Práticas da leitura. Tradução Cristiane Nascimento. 2. ed. rev. São Paulo: Estação Liberdade, 2001.

DANTAS, Dom Adelino. De que morriam os sertanejos do Seridó antigo? Tempo Universitário, Natal, v. 2, n. 1, 130-136, 1979.

DICKENS, A. G. A contra reforma. Tradução António Gonçalves Mattoso. Lisboa: Editorial Verbo, 1972.

FARIA, Sheila de Castro. A Colônia em movimento: fortuna e família no cotidiano colonial. 2 reimp. São Paula: Nova Fronteira, 1998.

FREGUESIA DA GLORIOSA SENHORA SANT'ANA. Livro de óbitos (1811-1838). (Manuscrito). In: DANTAS, Dom Adelino. Homens e fatos do Seridó antigo. Garanhuns: Gráfica do "O Monitor", [1961].

GINZBURG, Carlo. Mitos, emblemas, sinais: morfologia e história. Tradução Frederico Carotti. 2. reimp. São Paulo: Companhia das Letras, 1989.

HALE, J. P. A Europa durante o renascimento (1480-1520). Tradução António Sabler. Lisboa: Editorial Presença, 1983.

KEMPIS, Tomás de. Imitação de Cristo. Tradução Pietro Nassettti. São Paulo: Martin Claret, 2005.

LABROUSSE, Ernest. Introdução. In: GODINHO, Vitoriano Magalhães (Dir.). A história social: problemas, fontes e métodos. Lisboa: Edições Cosmos, 1973. (Colóquio da Escola Normal Superior de Saint-Cloud, 15 e 16 de maio de 1965).

LE GOFF, Jacques. São Luís: biografia. Tradução Marcos de Castro. 3. ed. Rio de Janeiro: Record, 2002. 
LIMA, Nestor. Municípios do Rio Grande do Norte: Baixa Verde, Caicó, Canguaretama, e Caraúbas. Mossoró: s.e. 1990. (Coleção Mossoroense, v. 596).

LYRA, Augusto Tavares de. História do Rio Grande do Norte. 3. ed. Natal: Instituto Histórico e Geográfico do Rio Grande do Norte, 1998.

MACÊDO, Muirakytan Kennedy de. A penúltima versão do seridó - uma história do regionalismo seridoense. Natal: Editora Sebo Vermelho, 2005.

MEDEIROS FILHO, Olavo de. Cronologia seridoense. Mossoró (RN): Fundação Guimarães Duque, 2002. (Coleção Mossoroense, v. 1268).

MEDEIROS FILHO, Pe. João; FARIA, Oswaldo Lamartine de. Seridó - Séc. XIX (fazendas e livros). 2. ed. Rio de Janeiro: Saraiva, 2001.

MOTT, Luiz. Cotidiano e vivência religiosa: entre a capela e o calundu. In: SOUZA, Laura de Mello e. (Org). História da vida privada no Brasil - cotidiano da vida privada na América portuguesa. 7. reimp. São Paulo: Companhia das Letras, 1997. (v. 1).

NASCIMENTO, Joaquina Maria do. Testamento e autos de contas. Vila do Príncipe /Freguesia da Gloriosa Senhora Sant'Ana, 1852. (Documento manuscrito de 20 de agosto de 1850, sob a guarda do Laboratório de Documentação Histórica do Centro de Ensino Superior do Seridó/LABORDOC - Caicó/Documentação do projeto de pesquisa "Os mortos vistos pelos vivos: atitudes perante a morte no Príncipe no século XIX").

PORTUGAL/BRASIL. Ordenações Filipinas. Rio de Janeiro: Edição de Cândido Mendes de Almeida, 1870. (5 volumes). Disponível em:

<http://www1.ci.uc.pt/ihti/proj/filipinas/ordenacoes.htm> Acesso em: 17 jul. 2008.

POVOAÇÃO DO CAICÓ. Ata da Instalação da Povoação do Caicó. In: MEDEIROS FILHO, Olavo de. Índios do Açu e Seridó. Brasília: Centro Gráfico do Senado Federal, 1984.

SILVA, Gonçalo Correia da. Testamento e autos de contas. Cidade do Príncipe/Freguesia da Gloriosa Senhora Sant'Ana, 1873. (Documento manuscrito de 8 de agosto de 1873, sob a guarda do Laboratório de Documentação Histórica do Centro de Ensino Superior do Seridó/LABORDOC - Caicó/Documentação do projeto de pesquisa "Os mortos vistos pelos vivos: atitudes perante a morte no Príncipe no século XIX”).

Artigo recebido em: 05/02/2009

Aprovado para publicação em: 15/05/2009 